\title{
Lenalidomide-Dexamethasone Regimen
}

National Cancer Institute

\section{Source}

National Cancer Institute. Lenalidomide-Dexamethasone Regimen. NCI Thesaurus. Code C64732.

A regimen consisting of lenalidomide and dexamethasone used to treat relapsed or refractory plasma cell myeloma. 